\title{
EHMTI-0328. Comparative evaluation of pregabalin, gabapentin, carbamazepine and topiramat in migraine
}

\author{
A Docu Axelerad ${ }^{1 *}$, D Docu Axelerad ${ }^{2}$ \\ From 4th European Headache and Migraine Trust International Congress: EHMTIC 2014 \\ Copenhagen, Denmark. 18-21 September 2014
}

\section{Objective}

To compare the efficacy and safety of of pregabalin, gabapentin, carbamazepine and topiramat in migraine.

\section{Research design and methods}

In this observational study, 24 patients received pregabalin, gabapentin, carbamazepine and topiramat orally twice daily, each for 6 month with optional dose up titration (divided in four groups, each group has 6 patients). Pain diagnosis of migraine was made according to the second edition of the International Classification of Headache Disorders (ICHD-2) criteria and pain relief was measured by the patient's global assessment of efficacy, using the Migraine Disability Assessment Questionnaire (MIDAS). Treatment goals include restoring function and improving pain control.

\section{Results}

There was a significant improvement in pain with all treatments compared with their baseline values. There were no significant differences in various other outcome measures between the groups.

\section{Conclusions}

Both carbamazepine and topiramat demonstrated similar efficacy in migraine but pregabalin, gabapentin was less effective on pain.

No conflict of interest.

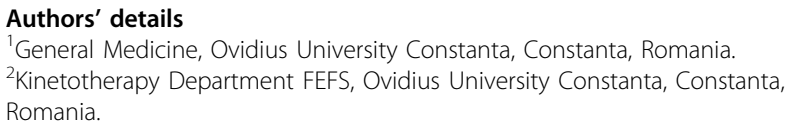

${ }^{1}$ General Medicine, Ovidius University Constanta, Constanta, Romania Full list of author information is available at the end of the article
Published: 18 September 2014

doi:10.1186/1129-2377-15-S1-G7

Cite this article as: Axelerad and Axelerad: EHMTI-0328. Comparative evaluation of pregabalin, gabapentin, carbamazepine and topiramat in migraine. The Journal of Headache and Pain 2014 15(Suppl 1):G7.

\section{SpringerOpen ${ }^{\odot}$}

C 2014 Axelerad and Axelerad; licensee Springer. This is an Open Access article distributed under the terms of the Creative Commons Attribution License (http://creativecommons.org/licenses/by/2.0), which permits unrestricted use, distribution, and reproduction in any medium, provided the original work is properly cited.
Submit your manuscript to a SpringerOpen ${ }^{\circ}$ journal and benefit from:

- Convenient online submission

- Rigorous peer review

- Immediate publication on acceptance

- Open access: articles freely available online

- High visibility within the field

- Retaining the copyright to your article

Submit your next manuscript at $>$ springeropen.com 